\title{
When push comes to shove in recreational fishing compliance, think 'nudge'
}

M. Mackay ${ }^{a, b, *}$, S. Jennings ${ }^{a, b}$, E.I. van Putten ${ }^{a, c}$, H. Sibly ${ }^{b}$, S. Yamazaki ${ }^{a, b}$

${ }^{a}$ Centre for Marine Socioecology, University of Tasmania, Battery Point, Tasmania 7004, Australia

b Tasmanian School of Business and Economics, University of Tasmania, Sandy Bay, Tasmania 7001, Australia

${ }^{c}$ CSIRO Oceans and Atmosphere, Hobart, Tasmania 7001, Australia

This is the peer-reviewed "accepted manuscript" of a paper originally published in Marine Policy. The final, formatted version may be found at 10.1016/j.marpol.2018.05.026.

\section{Abstract}

Enforcing compliance with rules and regulations in recreational fisheries has proved difficult due to factors such as the high number of participants and costs of enforcement, the absence of regular monitoring of recreational fishing activity, and the inherent difficulties in accurately determining catch levels. The effectiveness of traditional punitive deterrence is limited, yet current management is heavily reliant on this compliance approach. In this paper, the potential of behavioural based management is considered through a narrative review of the relevant literature; specifically, exploring the use of nudges, which aim through subtle changes and indirect suggestion to make certain decisions more salient, thereby improving voluntary compliance. This concept is explored with specific reference to the compliance of fishers within Australian recreational fisheries. There are only a few examples of behavioural based approaches found. However, based on their theoretical foundations, nudges may represent an inexpensive, and potentially highly effective tool for recreational fisheries management. Nudges do not offer a 'quick fix' to cases where traditional policy instruments have failed. Rather, there is the potential for behavioural nudges (based on framing, changing the physical environment, presenting default options, and social norms) to augment and complement existing deterrence regimes. A number of potential nudges for compliance management in recreational fisheries are suggested, but caution is advised. As with any novel management approach, nudges must be rigorously tested to demonstrate their cost-effectiveness and to avoid unintended consequences.

\section{Introduction}

Fishing is a popular recreational activity in many places around the world [128]. The global estimation of recreational fishing ${ }^{1}$ participation is around $11 \%$ of people [13] with an estimated number of fishers ranging between 220 million [47] and 700 million [36]. Recreational fishing provides participants with a number of social, economic and health benefits $[37,72]$ as well as a potential source of protein $[35,38]$. In some cases it also generates significant social and economic benefits to communities, for example through the flow-on economic and 
employment benefits arising from fisher expenditure and tourism [32]. Many recreational fisheries are managed under regulated open access regimes [69], which fail to fully curtail the destructive race behaviours characteristic of users of a common pool resource, which can result in excessive fishing capacity and user congestion, and overuse of fish stocks. Recreational fisheries are, therefore, prone to over-exploitation and with the most valued commercial species often targeted [33], recreational fisheries have been credited with contributing to global fisheries declines $[151,36]$. ${ }^{1}$ Recreational fishing is often defined as any recreational activity that removes aquatic organisms, including but
not limited to line fishing, spearfishing, netting and collecting [128].

Global recreational fisheries are generally understudied, poorly understood [153], and their scale and impact are largely underestimated $[118,35,86]$. For example, in Australia, recreational harvest is substantial and exceeds the commercial catch for a number of species, including Yellowtail Kingfish [88], Blue Swimmer Crab and Snapper [98]. More widely, monitoring, surveillance and enforcement efforts by management are well below those for commercial fisheries [60]. This is often due to capacity shortfalls in staff and financial resources [55] and consequently, very few comprehensive records of catch and effort exist [28]. The impacts of recreational fishing can affect size structure, stock abundance and evolutionary trajectories [86], and will be further heightened by technological improvements [98]. However, poor knowledge and understanding of these impacts challenges the effectiveness of sustainable management $[9,7]$. To date, initiatives to limit and control recreational fishing activity have focused on addressing symptoms and not on the underlying causes of problems because of this lack of understanding [36].

The overall approach to recreational fisheries management has tended to mirror that of the commercial fisheries with a heavy emphasis on the use of regulatory tools, such as effort regulation and catch limits [35]. Ensuring compliance with such regulations is therefore a key element in effective fisheries management. Non-compliance with regulations in the global conservation context remains one of the largest illegal activities in the world, resulting in degradation to societies, economies and the environment [61,7]. The threats that noncompliance poses on marine conservation and marine socio-ecological systems are also consequential; non-compliance has the potential to undermine management [129] and sustainability [78], and to create conflict between user groups $[35,79]$. Conversely, ensuring recreational fishers' compliance with rules and regulations is particularly difficult due to factors such as the high number of participants and costs of enforcement, the absence of regular monitoring of recreational fishing activity, and the inherent difficulties in accurately determining catches. While management of both sectors tends to emphasise instrumental factors like economic incentives and deterrence for ensuring compliance [108,81], the absence of formal management infrastructure in recreational fisheries (i.e. landing obligations, log books, electronic monitoring or on-board observers) renders this approach less effective and suggests the need for an alternative approach. 
Although recreational and commercial fisheries share a number of characteristics, and enforcement and management tend to be similar, the two are fundamentally different [42]. In particular, while commercial and recreational fishers both positively respond to catch rates, recreational fishers are generally more motivated by non-catch incentives [10]. Non-catch motivations can be broadly categorised into three groups; mastery motivations such as mental stimulation [73], achievement [70,82] and trophy winning [135]; social factors [45,95]; and escapism (White [148]; [68]). Since the main drivers for recreational fishing behaviour extend beyond the key economic drivers of commercial fishing, the instruments needed for effective management of recreational fishing are likely to differ from those used in commercial fisheries. Despite this, such instruments have typically dominated re-creational fisheries [39]. Moreover, the need to incorporate human dimensions for compliance management in recreational fisheries is increasingly being recognised and advocated for $[11,19,71]$ and the use of voluntary and informal institutions for recreational fisheries management have been suggested [39]. However, the application of behaviourally-based approaches for compliance management has yet to be explored.

The overall aim of this manuscript is to highlight how behavioural nudges may fill a critical gap in current fisheries management and improve recreational fishing compliance outcomes. The potential for lesser used, non-traditional approaches is highlighted through a narrative review of the peer reviewed literature on behavioural theory, specifically nudge theory. Nudge theory argues that through positive reinforcement or indirect suggestion, non-forced compliance can be achieved. The manuscript aim is achieved with specific reference to the case of Australian recreational fisheries, which have particularly high participation and a fisheries regulatory regime typical of developed countries. Additionally, there is a considerable wealth of literature on recreational fisheries in Australia, specifically with a focus on compliance. A brief background of relevant compliance theory is provided along with the definition of nudge theory (Section 2), followed by a review of the compliance issues and current management within Australian case literature (Section 3). This provides the context for discussing which behavioural nudges may be effective in influencing compliance behaviour, with examples provided (Section 4). The paper concludes by identifying a series of challenges and design considerations which will influence the effectiveness of nudges within recreational fisheries in Australia and elsewhere (Section 5).

\section{Compliance theory in recreational fisheries}

\subsection{Traditional compliance theory}

Compliance is defined for the purpose of this paper as adhering to the rules and regulations by recreational fishers. Compliance can be interpreted as either binary, i.e. no compliance vs. compliance, or as a spectrum, i.e. 'high', 'medium', 'low' [7]. The latter interpretation is more pertinent when considering compliance management as it is consistent with the notion that compliance is malleable and that gradual behavioural change can transition compliance along a gradient, rather than requiring behaviour to move from one opposite disposition to another. Non-compliance can be accidental or deliberate and can occur on a range of scales and frequencies, for example catching an undersized fish after a recent amendment to size 
restrictions, or a conscious, organised effort to catch a high value species with the intention to profit from sales. Compliance can be viewed as a function of deterrence and voluntary compliance. Deterrence is the outcome of deliberately implemented prevention tactics including the likelihood of getting caught and the severity of the repercussions. Voluntary compliance, on the other hand, occurs when people willingly choose to adhere to the rules and regulations regardless of the expected re- percussions of non-compliance [121].

Identifying the determinants of compliance and knowing what drives compliance behaviour is complex, and this is reflected in the evolution of compliance theories and models. Becker [15] was the first to model the broad components of compliance and to discuss how to choose enforcement levels. Based on the assumption of rational economic behaviour, this model assumes that the decision to infringe is based on the expected return to breaking the rules, taking into account the direct returns and costs of different compliance behaviours, and the risk of detection and punishment. Some fisheries compliance models have built on Becker's model to include some of the complexity, incorporating additional parameters including individual effort [6] and personality types [30]. However, they are still better equipped for ex-plaining compliance behaviour where economic drivers dominate (i.e. commercial fisheries) and inadequately capture the full complexity of the problem [111].

The recognition that compliance behaviour is not solely based on economic gains is expanding and is reflected in compliance models relaxing the assumption of pure instrumental rationality of agents and acknowledging the importance of normative behavioural drivers. Expansion of fisheries compliance models used concepts from psychology and sociology to extend the rational choice model to also include intrinsic values such as personal morality, social reputation and legitimacy [134,83]. Intrinsic values and informal management have been integrated within theoretical models of commercial fisheries $([108,65,93]$; Nøstbakken [111]; Xepapadeas [152]). However, only recently have compliance models been tested on recreational fishing compliance behaviour [144]. The integration of normative drivers results in better prediction of compliance behaviour, with psycho-social factors such as social norms, being the most significant driver compared to instrumental drivers [141]. Therefore, the predictors of compliance are broader than the earlier deterrence models assumed, and the instrumental factors, upon which recreational compliance management is largely based, might not be adequate. Understanding of normative drivers is yet to be adequately applied in management, as harnessing social norms, legitimacy and personal morality into action is challenging. However, this is a gap that nudges, as successfully trialled and tested tools in influencing behaviour in other domains, may fill.

\subsection{Nudge theory}

If deterrence relies on 'shoving' people to make certain decisions (such as complying with rules), a 'nudge' can be thought of as a more subtle way to encourage a decision that is in people's best interest. For example, while it is rationally in people's best interest to save for retirement, and most countries offer tax incentives to do so, people frequently still do not save enough for retirement [94]. A nudge to over- come this is to apply an auto-enrolment into 
saving schemes, to make this decision more salient and increase average saving rates (i.e. up to $13.6 \%[138])$.

The term 'nudge' was first coined by Thaler \& Sunstein in their book Nudge: Improving Decisions about Health, Wealth and Happiness (2008) with a nudge defined broadly as a change to "any aspect of choice architecture that alters people's behaviour in a predictable way without forbidding any options or significantly changing their economic incentives" $[139,6]$. Choice architecture refers here to the way in which options are presented to people that in turn may influence their choice. There have been a number of iterations of the definition of a nudge since Thaler and Sunstein $[101,139,64,66]$. The most encompassing definition is provided by Hansen [63]: 16 who states that a nudge is "a function of any attempt at influencing people's judgment, choice or behaviour in a predictable way (1) that is made possible because of cognitive boundaries, biases, routines and habits in individual and social decision-making posing barriers for people to perform rationally in their own declared self-interests and which (2) works by making use of those boundaries, biases, routines, and habits as integral parts of such attempts". The theory that underpins the ability of nudges to produce such changes is, therefore, primarily based upon insights from behavioural economics and encompasses ideas from both psychology and sociology $[149,75]$. In particular, nudges rely on understanding and being able to predict how and why human behaviour deviates from that predicted by standard economic theory. Nudges are designed interventions that target the behavioural biases that arise from the three acknowledged bounds of human behaviour ${ }^{2}$ [105].

Nudging, therefore, is about changing the choice environment to make certain options more salient, broadly through indirect suggestion or positive reinforcement. Equally important to understanding what a nudge is, is to understand what is not a nudge. Hansen [63];16 clarifies that "a nudge amongst other things works independently of: (i) for-bidding or adding any rational relevant choice options, (ii) changing incentives, whether regarded in terms of time, trouble, social sanctions, economic and so forth, or (iii) the provision of factual information or rational argumentation". For instance, in the context of compliance with a shorter catch season for the female of a species, according to the definition above the following would not be considered a nudge: (i) forbidding the catch of female all year round, which would forbid the choice option; (ii) incorporating a tagging system for females that is allocated through an application based lottery process, which would change incentives by increasing the effort required; (iii) providing factual information on the ecological importance of not catching females during spawning season.

\footnotetext{
${ }^{2}$ There are three acknowledged bounds which are; bounded rationality, which reflects the limited cognitive abilities that constrain human problem solving; bounded willpower, captures the fact that people sometimes make choices that are not in their long-run interest and bounded self-interest, incorporates the fact that humans are often willing to sacrifice their own interests to help others [104].
} 


\section{Current management and compliance issues: an Australian perspective}

\subsection{Current regulatory management}

The importance of recreational fisheries in Australia is recognised economically, culturally, and ecologically [26]. Recreational fishing participation in Australia is high, with about 3.5 million people (14\% of the population) fishing at least once each year [50]. Due to factors such as the extensive Australian coastline, the absence of regular monitoring of recreational fishers, and the high costs of enforcement, ensuring compliance with rules and regulations is challenging. Compliance in recreational fisheries has been of high interest in Australia, with numerous academic efforts made to better understand such a tenacious problem ([18]; Bergseth and Roscher [20]; [8,128]), as well as governmental and managerial efforts to improve compliance $[106,103,58]$. Sub-culture theory would suggest that groups, such as recreational fishers, share norms and values (Bergseth \& Roscher 2018; [49]). This, combined with the high participation rates and cultural importance recreational fishing has in Australia [68], makes it a good case for exploring the potential of behavioural nudges for enhancing compliance.

Within the Australian fishing zone it is the State and Territory governments that assume responsibility for recreational fishing [3], with a few larger pelagic species being the exception, such as Bluefin Tuna and certain shark species managed under Commonwealth and international jurisdiction [142]. Recreational fisheries in Australia are managed via a mixture of regulations and rules that either aim to control fishers' input or their output [103]. Input management aims to control who is allowed to fish, where they are allowed to fish, when they are allowed to fish and how they are allowed to fish. This includes any type of access controls such as licenses and fishing rights, as well as spatial controls such as protected areas. Output controls on the other hand address what and how much people are allowed to catch. This includes both quantitative and qualitative restrictions. Total allowable catch and bag limits are quantitative restrictions on the mass or numbers of fish harvested, whereas, qualitative output controls are restrictions on sex, species or size limits.

There are a number of consistencies and differences in management delivered across all state jurisdictions. There are uniform regulations on the removal of threatened species and every coastal jurisdiction has size, bag and possession limits for certain species with some also having boat limits. However, the specific details differ e.g. the size limit for Bream in Tasmania is $25 \mathrm{~cm}$ but it is $30 \mathrm{~cm}$ in South Australia. For reasons such as protecting spawning stocks during reproductive periods, there are temporal closed seasons in every jurisdiction, except the Northern Territory. There are some differences in the requirements for recreational fishing licenses across Australia. For example, while re- creational fishers in New South Wales and Victoria require licenses for any fishing activity, in the Northern Territory, South Australia and Queensland they do not require general or specific gear or species licenses for recreational fishing activities. Within Western Australia and Tasmania, fishers do not require general recreational fisheries licenses but there are gear and species specific licenses (for species such as Western and Southern Rock Lobster, respectively). 
Through monitoring and enforcement of these regulations, punishments for non-compliance include issuing fines, loss of fishing licenses and for extreme cases, imprisonment. Empirical research on compliance in green zones within the Great Barrier Reef in Australia found that the fear of being fined is ranked as the highest compliance driver for not fishing within marine reserves [8], however the perception of higher catches in reserves and a low probability of detection are ranked as the primary motivations of non-compliant behaviour within these reserves [18]. In a New Zealand recreational fishery, instrumental factors, such as probability of detection and probability of conviction, were found not to be significant drivers of compliance behaviour [141], and generally compliance management solely based on economic incentives targeting deterrence has been questioned [12]. Accordingly management is being advised to emphasise and encourage voluntary compliance behaviour ([7,8]; Bergseth and Roscher, 2018).

\subsection{Compliance issues}

The review of compliance issues is delivered as a narrative review that considers academic, policy and grey literature in order to provide context for the subsequent discussion of behavioural incentives. This literature review highlighted some pertinent compliance issues within recreational fisheries in Australia, including but not limited to the ten compliance issues found in Table 1. Of these compliance issues, five represent violations of input controls with examples of issues violating each of the four types of input control (i.e. who, where, when and how). Fishing without a license, for example, violates management controls that prescribe who is permitted to fish, and fishing with restricted gear is non-compliance with how to fish. The remaining five issues represent violations of output controls, with what was being caught comprising the majority of the compliance issues, including retaining juvenile fish, ignoring biotoxin or consumption warnings, illegal selling of catch and fishing for protected species. The other output control that was violated was regarding how much is being caught i.e. exceeding catch limits. A number of the compliance issues raised within this review relate to violations of output controls, relating to what and how much is being caught, suggesting these controls may require additional management tools for compliance. Table 1 also provides specific examples of each of the compliance issues, a description of the current legislation and maximum financial punishment, the type of monitoring and, if suggested in the literature, an alternative, non-fiscal management alter- native. Currently the majority of compliance issues are managed through deterrence based legislation requiring some sort of monitoring, with few examples of informal enforcement or compliance measures targeting voluntary compliance.

The financial repercussions for fishers who do not comply with regulations ranged from a $\$ 50$ on the spot fine, to as much as $\$ 400,000$ for trafficking a commercial quantity of a priority fish species [147]. A national study of crime in the Australian fishing industry stated that stakeholders believe legislation had inadequate penalty provisions and there was doubt in the prosecution and sentencing [121]. This is reflective of generally low conviction rates globally for recreational fisheries with a noted rarity of prosecution of fisheries crime and leniency when it does occur [100]. Overall perceived low conviction rates may reflect the fact that in jurisdictions other than Victoria and New South Wales, numbers of convictions and fines are not publicised, for example through fisheries department websites [112,143]. Other forms of information sharing is used, for example through press releases on successful convictions and increases in 
monitoring within the Great Barrier Reef, in New South Wales [54], and fisheries departments sharing convictions on non-compliance on Facebook, which will reinforce the norm and perception of enforcement [136].

In addition to the laws and regulations in place to manage the non-compliance issues, there were also non-fiscal incentive-based ways of addressing compliance that touch on behavioural understanding (Table 1). These include co-management, and increased participation in, and expansion of, volunteer programs. These types of initiatives build upon trust and legitimacy of user groups, which have been shown to encourage compliance $[77,93]$. Every State has an illegal fishing hotline for members of the public to report any illegal fishing activity they witness such as Fishwatch in Tasmania and New South Wales or 13FISH in Victoria. There is no punishment for not reporting any illegal activity through the hotline and generally there is no financial incentive to do so. The presence of self-monitoring by peers is a benefit to any compliance management as it increases monitoring capability and reinforces social acceptability of behaviours. The Great Barrier Marine Park Authority are disseminating a number of press releases on compliance convictions, emphasizing the punishments and unacceptance associated with poaching within the marine reserve [54]. Another example of reinforcing social acceptability is through a shame file (Hook, line and stinkers) produced with government input, such as that published in a Queensland paper that listed cautionary tales of non-com- pliant convictions (without naming the culprits) along with reminders of the rules and regulations and illegal fishing hotline [62]. Although there is no empirical evidence to suggest this specific example is effective in changing behaviour, a field experiment tested the influence of shame on voter attendance in the US and found that people complied with voting norms when non-voters were named in a local newspaper and the risk of shame was present [117]. Thus, using a shame file in a local newspaper may be an effective addition to laws and regulations for regulation compliance.

There is generally little information available on actual compliance rates. The crude rate of noncompliance - which is calculated by looking at the number of offences that are weighted by severity over the total number of contacts made by fisheries officers - in Western Australia remained around six offences per every 100 checks from 2000 to 2007 [58]. More recently, as many as $18 \%$ of surveyed fishers ad- mitted to poaching in the last year within the Great Barrier Reef Marine Park [18]. It has been said that the number of observed offences will be a function of enforcement effort as a fraction of the total number of offences committed [58], with a suggested hypothetical relationship between enforcement effort and offences. While this estimation is useful as it offers an opportunity to derive a rough calculation for compliance rates it neglects the offences that are prevented through efforts other than deterrence. For example, the compliance issues associated with territory conflicts are predominantly selfmonitored, and non-compliance with consumption warnings for biotoxins are also selfmonitored (Table 1). While coercive measures such as fines and prosecution are appropriate for recidivists or serious offenders, persuasion and warning based compliance strategies can be used to influence accidental non-compliers [7]. Managers may overlook self-regulation and voluntary compliance as compliance tools since there is no direct measure of their impact on convictions. 
Table 1. Common compliance issues within Australian recreational fisheries and associated legislation, financial punishment, and monitoring, and if noted any non-fiscal incentives for combating non-compliance.

\begin{tabular}{|c|c|c|c|c|c|c|c|c|}
\hline \multicolumn{2}{|c|}{$\begin{array}{l}\text { Management } \\
\text { method }\end{array}$} & \multirow{2}{*}{$\begin{array}{l}\text { Compliance issue } \\
\text { Fishing without a license }\end{array}$} & \multirow{2}{*}{$\begin{array}{l}\text { Example } \\
\text { Fisherman fined after being } \\
\text { caught without licence in New } \\
\text { South Wales (NSW Department of } \\
\text { Fisheries [113]) }\end{array}$} & \multirow{2}{*}{$\begin{array}{l}\text { Current legislation } \\
\text { Fisheries Management Act } \\
1994 \text { of New South Wales }\end{array}$} & \multirow{2}{*}{$\begin{array}{l}\text { Financial Punishment } \\
\$ 200 \text { on the spot fine and } \\
\text { upwards of } \$ 210-2500\end{array}$} & \multirow{2}{*}{$\begin{array}{l}\text { Type of monitoring } \\
\text { Fisheries officers }\end{array}$} & \multirow{2}{*}{$\begin{array}{l}\text { Non-fiscal incentives } \\
\text { Voluntary code of conduct }\end{array}$} & \multirow{2}{*}{$\begin{array}{l}\text { Literature cited } \\
{[59,89,113]}\end{array}$} \\
\hline Input & Who & & & & & & & \\
\hline & Where & Fishing within protected areas & $\begin{array}{l}\text { Fishing within green zones in the } \\
\text { Great Barrier Reef Marine } \\
\text { Protected Area, and the Ningaloo } \\
\text { Marine Park }([21,128]\end{array}$ & $\begin{array}{l}\text { The Environment Protection } \\
\text { and Biodiversity Conservation } \\
\text { Act } 1999\end{array}$ & $\begin{array}{l}\text { fines, confiscation of } \\
\text { property court hearing } \\
\text { warnings and jail }\end{array}$ & $\begin{array}{l}\text { Aerial \& vessel-based } \\
\text { surveillance, indirect } \\
\text { observations, reports \& on site } \\
\text { observations }\end{array}$ & $\begin{array}{l}\text { Increased involvement of } \\
\text { fishers in planning }\end{array}$ & {$[21,96,122,126,128]$} \\
\hline & & $\begin{array}{l}\text { Not complying with territory } \\
\text { rules resulting in conflicts } \\
\text { between users/ interfering with } \\
\text { others gear }\end{array}$ & $\begin{array}{l}\text { Conflict between recreational and } \\
\text { commercial fishers in New South } \\
\text { Wales/ } \\
\text { Western Australian [14] }\end{array}$ & $\begin{array}{l}\text { Fisheries Act } 2010 \text { Commercial } \\
\text { fisher gets priority }\end{array}$ & Maximum penalty $\$ 50$ & Self-reporting & $\mathrm{N} / \mathrm{A}$ & \\
\hline & When & Fishing within closed season & $\begin{array}{l}\text { Western Australian fishermen } \\
\text { fishing within closed seasons (WA } \\
\text { News [144]) }\end{array}$ & $\begin{array}{l}\text { Fisheries management } \\
\text { (General) regulation } 2007\end{array}$ & $\begin{array}{l}\text { First offence }-\$ 10000 \text {; for } \\
\text { a second or subsequent } \\
\text { offence- } \$ 20000 \text {. }\end{array}$ & Aerial Surveys & Rights based fishing & {$[79,128]$} \\
\hline & How & $\begin{array}{l}\text { Not complying with gear } \\
\text { restrictions resulting in boat } \\
\text { impacts on environment }\end{array}$ & $\begin{array}{l}\text { Damage to seagrass beds/ reefs } \\
\text { from unsuitable gear in Victoria } \\
{[80]}\end{array}$ & $\begin{array}{l}\text { Fisheries Act } 1995 \text { of Victoria. } \\
\text { The Great Barrier Reef Marine } \\
\text { Park Act } 1975\end{array}$ & $\begin{array}{l}\$ 2,000-\$ 10,000 \text { in Great } \\
\text { Barrier Reef Marine Park } \\
\text { Authority }\end{array}$ & $\begin{array}{l}\text { Community reporting of } \\
\text { ecological data }\end{array}$ & $\begin{array}{l}\text { Codes of conducts and } \\
\text { restricted access penalties } \\
\text { not just monetary }\end{array}$ & {$[57,80]$} \\
\hline \multirow[t]{5}{*}{ Output } & What & Illegal selling of catch & $\begin{array}{l}\text { Failing to clip the tail rock lobster } \\
\text { to sell on }[120]\end{array}$ & $\begin{array}{l}\text { Fisheries management } \\
\text { (General) regulation } 2007\end{array}$ & Max penalty $\$ 5,000$ & Marine police & Community reporting & {$[80,120]$} \\
\hline & & Fishing for protected species & Queensland shark finning [127] & $\begin{array}{l}\text { Fish resources management } \\
\text { Act } 1994\end{array}$ & $\$ 1000-\$ 5000$ & On site landing checks & $\begin{array}{l}\text { Using length instead of } \\
\text { mass in trophy fishing }\end{array}$ & [127] \\
\hline & & $\begin{array}{l}\text { Individuals ignoring biotoxin/ } \\
\text { consumption warnings/ } \\
\text { advisories }\end{array}$ & $\begin{array}{l}\text { Fishing and eating during biotoxin } \\
\text { closures in Tasmania }[137]\end{array}$ & Informal / advisory & $\mathrm{N} / \mathrm{A}$ & N/A & $\begin{array}{l}\text { Co-management assisting } \\
\text { with risk assessment and } \\
\text { risk management }\end{array}$ & {$[27,137]$} \\
\hline & & Retention of juvenile fish & $\begin{array}{l}\text { Keeping juvenile finfish in South } \\
\text { Western Australia [1] }\end{array}$ & $\begin{array}{l}\text { Fish Resources Management } \\
\text { Act } 1994 \text { of Western Australia }\end{array}$ & $\$ 2,000$ & Fisheries officers & $\begin{array}{l}\text { Expansion of volunteer } \\
\text { programs }\end{array}$ & {$[1,25,80,98]$} \\
\hline & $\begin{array}{l}\text { How } \\
\text { much }\end{array}$ & Exceeding catch limits & $\begin{array}{l}\text { Queensland fisherman caught } 50 \\
\text { times the limit [62]; Western } \\
\text { Australian fishers caught } 405\end{array}$ & $\begin{array}{l}\text { Fisheries Act } 1994 \text { of } \\
\text { Queensland. Fish Resources } \\
\text { Management Act } 1994 \text { of }\end{array}$ & $\begin{array}{l}\$ 4,000 \\
\text { Penalties up to } \$ 400,000\end{array}$ & $\begin{array}{l}\text { Queensland Boating and } \\
\text { Fisheries Patrol (QBFP) } \\
\text { district officer } \\
\text { Fisheries officers }\end{array}$ & $\begin{array}{l}\text { Shame file in Queensland } \\
\text { paper }\end{array}$ & {$[14,62,147,150]$} \\
\hline
\end{tabular}




\section{Potential nudges in recreational fisheries}

As demonstrated through the discussion of Australian compliance issues, even when punitive methods are in place non-compliant behaviours can persist and additional management levers may need to be deployed. Nudges may be a potential, innovative tool to bolster traditional management by encouraging voluntary compliance by making certain decisions more salient. The use of nudges in public policy has increased over the past decade [17], including examples in energy conservation and energy efficiency investments, transport choices, water conservation and sustainable food consumption $[115,116]$. Examples specifically targeting compliance behaviour can be found in taxation [29,87] and environmental regulation [16]. While the use of nudges in marine management has been advocated for [43] there is little evidence of their application in addressing compliance issues in recreational fisheries management. A commonly used typology of nudges comprises four different types; i) simplification and framing of information, ii) changes to physical environment, iii) changes to the default policy and iv) use of social norms and comparisons $[102,85]$. This typology is used along with the extant literature on applied nudges in other sectors to identify a series of potential nudges that can be tailored to the recreational fishing compliance problem. Table 2 and the following sections describe these examples, linking each to the typology, the compliance issues and associated management control method it is intended to address.

Table 2. Potential nudges for addressing compliance issues in recreational fishing.

\begin{tabular}{|c|c|c|c|c|}
\hline \multicolumn{2}{|c|}{ Management method } & \multirow{3}{*}{$\begin{array}{l}\text { Compliance Issue } \\
\text { Fishing without a license }\end{array}$} & \multirow{2}{*}{$\begin{array}{l}\text { Behavioural Nudge } \\
\text { Social norms / simplification and } \\
\text { framing of information }\end{array}$} & \multirow{2}{*}{$\begin{array}{l}\text { Potential recreational fishing application } \\
\text { Wording of licenses/ statistics e.g. } 23 \% \text { of people were checked by } \\
\text { marine police last year/ } 90 \% \text { of people display their license ID number } \\
\text { on their potting floats }\end{array}$} \\
\hline Input controls & Who & & & \\
\hline & & & Defaults & Automatic renewal for licenses \\
\hline & Where & Fishing within a protected area & Defaults & 'Opting-in' to voluntary closures with the option to opt out \\
\hline & When & Fishing in a closed-season & $\begin{array}{l}\text { Use of social norms and } \\
\text { comparisons }\end{array}$ & $\begin{array}{l}\text { Regulation reminders including comparisons to previous year's fishers' } \\
\text { opinions/ compliance rates }\end{array}$ \\
\hline & How & $\begin{array}{l}\text { Not complying with gear } \\
\text { restriction/ gear impacts on } \\
\text { environment }\end{array}$ & Defaults & Default subscription to conservation efforts as extra payment of license \\
\hline \multirow[t]{3}{*}{ Output controls } & What & Illegal selling of catch & Changes to physical environment & Eyes on boards at boat ramps \\
\hline & & Retaining juveniles/ undersized fish & $\begin{array}{l}\text { Simplification and faming of } \\
\text { information/ } \\
\text { Changes to physical environment }\end{array}$ & $\begin{array}{l}\text { Rephrase regulation reminders on apps from juvenile to baby fish/ little } \\
\text { ones. Persuasive messaging on measuring rulers. } \\
\text { Spray paint size limits at popular spots (Fig. 1) }\end{array}$ \\
\hline & How much & Exceeding a catch limit & $\begin{array}{l}\text { Simplification and framing of } \\
\text { information }\end{array}$ & Persuasive messaging and anchoring catch limit below legislated limit \\
\hline
\end{tabular}

\subsection{Simplification and framing of information}

Framing is already being used in recreational fisheries management to encourage compliance, for example, persuasive messaging can be seen on the ruler distributed by the Inland Fisheries Service that can be used to measure Tasmanian trout (Fig. 1a). At the legal minimum size limit the message "It may be to size but do you really want it" appears then along the ruler at increasing measurements it states "Not bad!" "Impressive!", "Worth bragging about!" then "Officially a monster!" (Fig. 1a). This type of messaging is intended to encourage fishers to aim higher than the minimum size by removing the size limit as the anchor and reduce the likelihood of fishers keeping anything below the size limit. Reframing information can also involve the use of descriptive words alongside informative words, for example "Grandma's Zucchini cookies" instead of "Zucchini cookies" increased sales by $27 \%$ [85]. A comparable 
nudge is already being applied in Tasmania's FishCare key messages, stating "Put the little ones back gently" to encourage fishers not to retain juvenile or undersized fish (Fig. 1b).

Another nudge in fisheries management in Australia has been applied through the framing of the catch limit in a cattle and camping station in Western Australia. It states; "Ideally we would like visitors to take no more than 2 fish per day to ensure the sustainability of this wonderful resource. We have a possession limit of $5 \mathrm{~kg}$. Catch a fresh fish each day, no need to freeze, there is no comparison to the taste" [146]. By first introducing a lower bag limit than the limit of 5 as set by the Western Australia State regulation (for the Gascoyne coast), people tend to use that as an anchor or reference point, and they will be primed ${ }^{3}$ to act according to this. The message is also framed based on personal gain from catching fresh fish and using descriptive words (i.e. protect the 'wonderful' resource), rather than framing non-compliance as a punishable offence. Framing has also been used as a nudge in healthcare, where patients were more likely to commit to having surgery when they were told ' $90 \%$ of people survived after five years' versus being told that 'after five years $10 \%$ did not survive' [97]. A similar nudge in recreational fisheries could be applied in reporting enforcement statistics, for example, ' $23 \%$ of people were checked by marine police last year' rather than ' $73 \%$ of people were not checked by marine police last year'.

${ }^{3}$ Priming, here, refers to the cues that can unconsciously drive behaviour [52], for example, how background music will subconsciously influence wine choices [110] and description of taste [109].

\subsection{Changes to physical environment}

Changes to the physical environment can act as a reminder or can deliver a message regarding social acceptability. An example is currently being used to reiterate the size limits of a popular recreational fish in Tasmania where the government has spray-painted a stylised picture of a Sand Flathead, along with the message "Measure your catch" (Fig. 1c) in certain locations. Changes to the physical environment like this have successfully reduced littering with green footprints painted on the ground leading to bins [92], and stickers near taps have assisted in water conservation [44]. Recent evidence has shown that people tend to act pro-socially when there is an image of eyes watching them. The influence of 'being watched' on people's motivations is twofold, a positive motivation to gain future reward by doing the right thing and a negative emotion to avoid violating an established norm [114]. The presence of eyes creates subtle cues of being watched and feeling seen, and it makes people act more honestly and prosocially, as well as inducing a public awareness [119]. This nudge could be applied in recreational fisheries by displaying some similar watching-eye installations at popular boat ramps along with messages about illegal selling of catch, fishing for protected species, or fishing without a li-cense. Additionally, the message along with a picture of eyes or someone looking through binoculars could be framed around encouraging fishers to report any non-compliance to further encourage self-monitoring on top of the cue to act more pro-socially.

\subsection{Changes to the default policy}

One of the most successful types of nudge is to change the default option. This builds from the understanding that many people dislike engaging in actively making a choice but instead will 
stick with the default [23]. Given this, if the default option is pro-environmental (or the type of behaviour managers want to encourage) it can have a large cumulative positive effect [125]. Large scale initiatives have been applied through default green energy policies. For example, in Germany $16 \%$ of energy providers automatically include their clients in green energy [133] by presenting this as the default option. There are a few examples of default nudges being applied in different Australian fisheries departments, but not yet targeting compliance. For example, de- faults are being used in Tasmanian fishing licenses, opting in for digital licenses [46], which will reduce costs for printing and posting, thus making more resources available for other purposes. In order to address compliance issues, an automatic license renewal could be established in recreational fisheries management to reduce the number of cases of nondeliberate fishing without a license. Incorporating default options in license renewals could include agreements to comply with voluntary closures or no go areas but with the possibility to opt out if they desired. There could also be additional fees included in the default to contribute to conservation initiatives to abate the impacts from boat or gear damage that has an opt-out option.

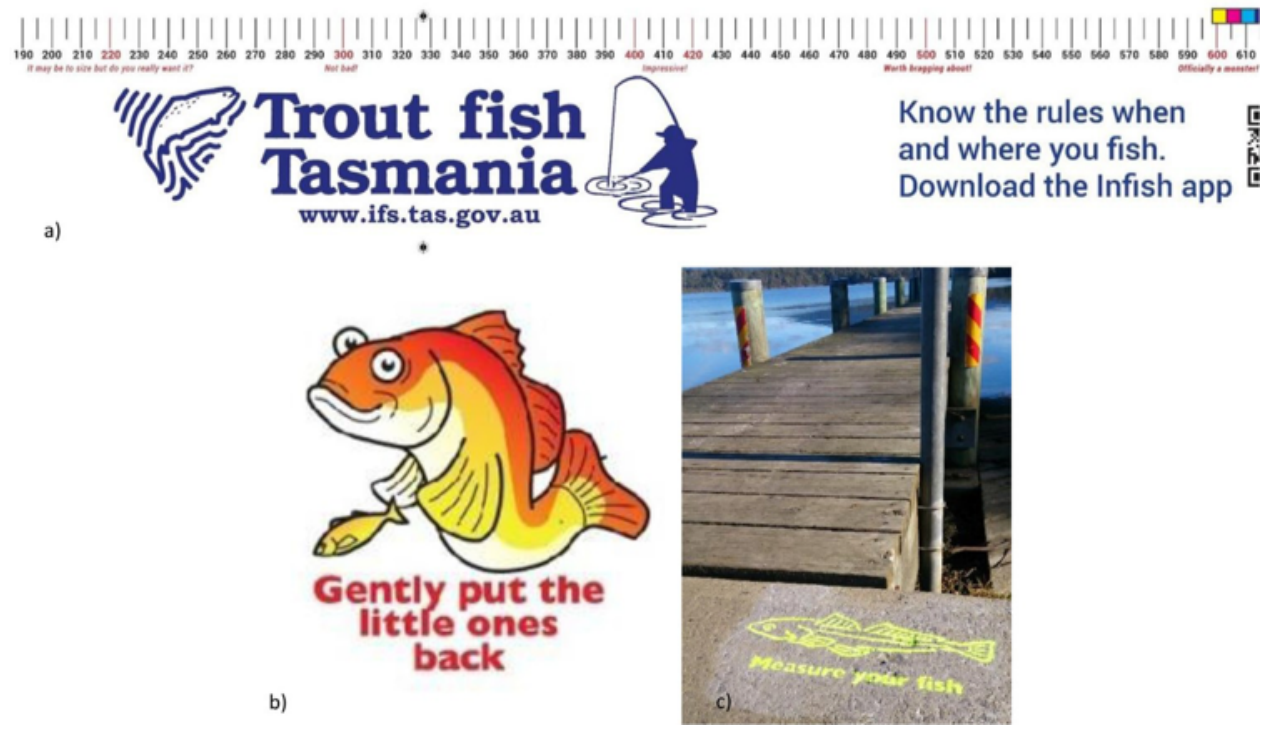

Figure 1. Examples of nudges used in Tasmanian recreational fishing and inland fisheries; a) an example of persuasive messaging regarding the minimum size of trout (text in red under the measurements); $b$ ) an example of simplification and framing nudge as part of the FishCare core messages to not retain juvenile or under- sized fish; $c$ ) an example of changes to the physical environment nudge with a spray-painted reminder to measure catch that is the same size as the minimum legal size of the commonly caught flathead.

\subsection{Use of social norms and comparisons}

As social beings, individuals are influenced by the actions of other's (social norms) and behaviours can be impacted through comparisons to peers (social comparisons). Within environmental management, in water and energy conservation, the practice of normative messaging has become an effective way to apply nudges $[4,48]$. For example, descriptive social norm-based messaging for water management was found to have an effect on a short and long term basis [22]. Experimentally social descriptive norms have also been found to increase cooperation between unknown subjects in common pool resource use when theoretically they 
should have behaved selfishly [24]. This suggests people's self-interest is bounded, because they are willing to sacrifice their own gains to help others [105].

Social norms have been shown to be particularly powerful in ex- plaining recreational fishing compliance behaviour [140] and is therefore likely an effective nudge. The presence of social norms on compliance behaviour can be observed through social media. For example, currently when a conviction of non-compliance occurs it will be widely circulated by some Australian Fisheries departments on Face- book. The response to these Facebook postings often include a disapproving discourse. A post regarding a conviction for retaining undersized fish received comments such as; "Should be a more hefty fine and lose gear" and "Name and shame" by other members of the group [136]. This experience can be used by fisheries departments as feedback to the wider community of the social norm regarding recreational non-compliance.

The strength of a social norm nudge can be increased with an in- junctive norm, which includes a consciousness of what is accepted or opposed by others [123]. Potential nudges that incorporate social norms and consciousness to elicit compliance in recreational fisheries could resemble feedback of previous fishers' decisions in response to a regulation. For example, 'According to last year's data the average fisher was happy to catch less than the bag limit'. This statement gives consciousness of the decision as well as reference to the norm. A nudge based on social norms can also be complemented by simplification and framing strategies (discussed above). For example, in Western Australia people are required to display their potting ID license. Reporting by the Western Australia government could apply a descriptive norm to encourage compliance by stating ' $90 \%$ of people display their license ID number on their potting floats' rather than " $10 \%$ of people don't display their license ID number on their potting floats" to elicit a change in behaviour.

\section{Challenges and design considerations for nudges in recreational fisheries}

Nudges vary in approach, application, and according to the type of choice that is being influenced, targeting either subconscious or conscious efforts (although most examples focus on the subconscious $[104,149,75])$. The use of nudges in public policy has not been without its critics, with concerns voiced about whether they are ethical [124], manipulative [34] or are a risk to human agency [145]. For example, the use of a social norm nudge aiming to reduce unnecessary laundering of towels in a hotel that used false statistics of reuse of other guests drew criticism on ethical grounds [56]. In defence of nudges as a legitimate instrument of public policy Sunstein [130] reiterates that they must preserve free choice, and while nudges can change people's behaviour by providing information in a different way or making certain decisions easier, they must not be coercive. In the case of recreational fisheries, nudges may pose an additional risk to the legitimacy and transparency of management if they are based on false statistics or re- place initiatives that require more resources like co-management and stakeholder engagement, which have been shown to encourage compliant behaviour in fisheries $[107,74,76]$. 
The effectiveness of nudges in creating the intended behavioural changes has also been questioned. For example, nudges that produce confusion, rather than simplifying choices, or nudges that result in re- active or 'boomerang' responses will be ineffective [131]. Within recreational fisheries, if fishers are not influenced by the actions of other's or want to defy other's expectations, they would not likely be influenced by a nudge using social norms and comparisons. For example, in a study on compliance behaviour within the Great Barrier Reef, 16-21\% of the fishers surveyed reported that they did not care if others approved of them poaching. This attitude strengthened as social distance increased, i.e. fishers cared what friends and family thought, but not what fishers they did not know thought (Bergseth \& Roscher 2018). This suggests that injunctive social norms around what other fishers think is accetable may not influence the behaviour of this sub-set of fishers and a social norm nudge based on this may not be effective. Some people may simply be emboldened by the prospect of disapproval and flouting convention, while other individual's reflective judgements may not align with the norm and therefore not be influenced by it [132].

Additionally, the longevity of the influence of a nudge may be in- consistent and a pattern of 'action and backsliding' has been identified in some applications [4]. When attempting to change habits, as in the case of energy consumption, new behavioural patterns may be slow to become adopted [99], therefore nudges should be applied on a regular basis to have a long term effect [5]. For recreational fisheries in which a one-time reminder of regulations or rules may cease to be salient and become background noise, nudges may need to be regular and periodically altered to stay meaningful and illicit a reaction. Additionally, compliance behaviour itself is dynamic, meaning that any management tool needs to be adaptive to account for this.

The effectiveness of nudges may be weakened where they produce compensating behaviour [131]. The history of fisheries management is replete with examples of such unintended consequences [2,31], for example with attempts to control total fishing effort regularly undermined by the ingenuity of fishers in substituting between various forms of controlled and uncontrolled effort i.e. when restrictions on the number of vessels results in increased vessel or engine size. Unintended compensating behaviours can also be expected in a recreational fisheries context. For example, in a recreational fishery in which a nudge improves compliance with spatial closures, but results in an increase in pressure outside the closed areas, with overall negative ecosystem outcomes. Failure to account for these effects may unintentionally decrease ecosystem health or overall compliance.

Poor or inaccurate understanding of the relevant choice environment can also contribute to ineffective nudges [131]. This reinforces the recent call for greater emphasis on better understanding of behavioural drivers of recreational fishers in complex socio-ecological systems $[11,19,71]$. Nudge design will be further complicated in cases where there are large differences across individuals in personal characteristics and behavioural drivers. Costa and Kahn [41] found evidence of varying effectiveness of an energy conservation nudge depending on political ideology and suggest that nudges need to be targeted to specific groups. The population of recreational fishers has been found to be highly heterogeneous in terms of socio-economic characteristics [51], attitudes [91], values [53], and motivations [40], suggesting that a 'one 
nudge fits all' approach to improving compliance is unlikely to work effectively and that multiple or different nudges will be needed to account for these groupings.

The interaction between traditional deterrence and nudge interventions in recreational fishing is unclear. Nudges to encourage compliance need to be implemented in a way that encourages voluntary compliance without negating or undermining the effectiveness of deterrence. While economic incentives, on which deterrence is based, can motivate prosocial behaviour they can also weaken altruistic values [84]. For example, enforcement of gear restrictions has led to increased overfishing perhaps through crowding-out of the intrinsic motivations that underpin voluntary compliance or by triggering extreme non-cooperative behaviour in response to those who break the rules [92]. The implied feedback system between voluntary compliance and deterrence, means that it is possible that deterrence and nudge interventions are substitutes or complements. Understanding the nature of this interaction is critical to successful nudge design.

Effective nudge implementation in recreational fisheries requires a systematic and rigorous design process. To this end, Ly et al. [90] suggest creating a 'decision map', outlining the critical actions involved with following through with a decision, such as whether to comply with a recreational fishing bag limit regulation or not. This involves considering broad properties of the decision (incentives and motivations), information sources, features of the individual's mindset and environ- mental/ social factors. From this decision map, factors that prevent individuals from following through with their intention can be identified. These factors, which can be thought of as 'bottlenecks', are the points at which potential nudges may result in efficient behaviour changes and where nudge efforts should be concentrated i.e. the biggest bottleneck will have the greatest potential for a nudge to have the most influence [90]. Understanding possible behavioural influences, such as status quo or confirmation bias, and heuristics, like anchoring and social proof, involved in these bottlenecks informs the selection and de- sign of a nudge.

To account for the complexities of the behaviour of common pool marine resource users and for the fact that recreational fisheries are often based on stocks that are shared with other user groups, it will be important that potential compliance nudges are tested in a systematic and controlled manner, for example through repeatable field and laboratory behavioural experiments. Within this context, difficulties in predicting the behaviour of fishers and their reactions to other fishers' behaviour, the transient and occasional nature of recreational fishing, and the heterogeneity of fishers will need to be accounted for. Additionally, the ambiguous outcome of combining deterrence and nudge intervention will need to be acutely considered. The 'test, learn, adapt' approach (Haynes et al. [67]) (developed by the Behavioural Insights Team in UK and adopted by Australian Behavioural Insights Team) provides a useful model for progressing the use of recreational fishing compliance nudges, and is consistent with the adaptive management approach used in Australia and elsewhere. The iterative nature of this approach is essential when considering fisheries management, which has to take account of a dynamic environmental, social, economic and political environment. 
As highlighted above, targeting the complex cognitive biases that influence individual choice and behaviour to produce improved recreational fishing compliance outcomes through nudges is likely to be challenging. Nudges do not offer a quick fix to replace cases where traditional policy instruments have failed. Rather there is the potential for behaviourally-based management to augment and complement existing deterrence regimes and, while suggesting a number of potential nudges for compliance in recreational fisheries, caution is advised. As with any new and novel management approach, nudges need to be rigorously tested to demonstrate their cost-effectiveness and to avoid unintended consequences.

\section{Conclusion}

Recreational fisheries management aims to promote both sustain- able and high quality recreational fishing activities. However, knowledge about compliance rates of recreational fishers is scant and concerns have been raised over the impact of potential breaches in recreational fishing compliance at all scales. The effectiveness of traditional punitive deterrence is limited, yet compliance management is heavily reliant on this enforcement and monitoring intensive compliance approach, which is costly and seem to be associated with poor conviction records. In this paper, the potential of behavioural based management, specifically nudges, to complement traditional deterrence approaches to help improve compliance in recreational fisheries is explored. Within Australia there are only a few examples of behavioural based measures in recreational fisheries compliance management found. However, based on their theoretical foundations, nudges may present an inexpensive, and potentially highly effective opportunity for recreational fisheries management. A number of potential nudges that could be used to complement current compliance management (based on framing, changing the physical environment, presenting default options, and social norms) are suggested, albeit with caution. The history of fisheries management is replete with examples of unintended consequences, and hasty implementation of under-tested and poorly designed nudges might not achieve the desired results. However, through careful design and when embedded within an adaptive management framework, nudges have the potential to contribute to improved recreational compliance thereby avoiding the threats that non-compliance poses to marine systems, locally and globally.

\section{Acknowledgements}

We would like to thank the recreational fisheries managers who helped us understand the types of behavioural incentives that had been implemented in their State jurisdictions. We would also like to thank Chris Cvitanovic for useful feedback and comments on an earlier draft of this manuscript and his tenacious encouragement throughout. We would like to thank Rachel Kelly and Thomas Botterill-James for useful editorial assistance. We would also like to thank the anonymous reviewer for providing insightful comments. Any remaining errors remain responsibility of authors. 


\section{References}

1. $\quad \mathrm{ABC}$, Australian Broadcasting Corporation. News. Fishers fined $\$ 2 \mathrm{~K}$ for undersized fish. Available at /http://www.abc.net.au/news/2012-04-10/fishers-fined-2k-forundersized-fish/3941050) (accessed August 4, 2017).

2. J.K. Abbott, A.C. Haynie, What are we protecting? Fisher behavior and the unintended consequences of spatial closures as a fishery management tool, Ecol. Appl. 22 (3) (2012) 762-777.

3. AFMA, Australian Fisheries Management Agency. Administration of the Domestic Fishing Compliance Program. Austalian National Audit Office Canberra, 2013.

4. H. Allcott, Social norms and energy conservation. Working Paper, Massachusetts Institute of Technology (July), 2009.

5. H. Allcott, T. Rogers, The Short-Run and Long-run Effects of Behavioral Interventions: Experimental Evidence from Energy Conservation, Am. Econ. Rev. 104 (2014), pp. 3003-3037.

6. L.G. Anderson, D.R. Lee, Optimal governing instrument, operation level, and enforcement in natural resource regulation: the case of the fishery, Am. J. Agric. Econ. 68 (3) (1986) 678.

7. A. Arias, Understanding and managing compliance in the nature conservation context, J. Environ. Manag. 153 (2015) 134-143.

8. A. Arias, S.G. Sutton, Understanding recreational fishers' compliance with no-takeno-take zones in the Great Barrier Reef Marine Park, Ecol. Soc. 18 (4) (2013).

9. A. Arias, et al., Optimizing enforcement and compliance in offshore marine protected areas: a case study from Cocos Island, Costa Rica, Oryx 50 (1) (2016) 1826.

10. R. Arlinghaus, On the apparently striking disconnect between motivation and satisfaction in recreational fishing: the case of catch orientation of German Anglers, North Am. J. Fish. Manag. 26 (3) (2006) 592-605.

11. R. Arlinghaus, et al., Recommendations for the future of recreational fisheries to prepare the social-ecological system to cope with change, Fish. Manag. Ecol. 23 (34) (2016) 177-186.

12. R. Arlinghaus, T. Mehner, I.G. Cowx, Reconciling traditional inland fisheries management and sustainability in industrial countries, with emphasis on Europe, Fish. Fish. 3 (2002) 261-316.

13. R. Arlinghaus, R. Tillner, M. Bork, Explaining participation rates in recreational fishing across industrialised countries, Fish. Manag. Ecol. 22 (1) (2015) 45-55.

14. A. Beattie. Boats seized, fishermen face nearly $\$ 1 \mathrm{~m}$ in fines as fishing crackdown continues. WA Today [online] p.1, 2016. Available at: 〈http://www.watoday.com. au/wa-news/boats-seized-fishermen-face-nearly-1m-in-fines-as-fishing-crackdowncontinues-20161224-gthnbd.html) (accessed 14 October 2017).

15. G. Becker, Crime and punishement: an economic approach, J. Political Ecol. 76 (1968) 169-217.

16. Behavioural Insights Team, The Behavioural Insights Team Update Report 20132015, London, 2015. 
17. S. Benartzi, et al., Should governments invest more in nudging? Psychol. Sci. 28 (8) (2017) 1041-1055.

18. B.J. Bergseth, et al., A social-ecological approach to assessing and managing poaching by recreational fishers, Front. Ecol. Environ. 15 (2) (2017) 67-73.

19. B.J. Bergseth, Effective marine protected areas require a sea change in compliance management, ICES J. Mar. Sci. (2017) 1-3.

20. B.J. Bergseth, M. Roscher, Discerning the culture of compliance through recreational fisher's perceptions of poaching, Mar. Policy 89 (2018) 132-141.

21. B.J. Bergseth, G.R. Russ, J.E. Cinner, Measuring and monitoring compliance in notake marine reserves, Fish. Fish. 16 (2) (2015) 240-258.

22. M. Bernedo, P.J. Ferraro, M. Price, The persistent impacts of norm-based messaging and their implications for water conservation, J. Consum. Policy 37 (3) (2014) 437452.

23. J. Beshears, et al., How are preferences revealed? J. Public Econ. 92 (8-9) (2008) 1787-1794.

24. A. Biel, J. Thøgersen, Activation of social norms in social dilemmas: a review of the evidence and reflections on the implications for environmental behaviour, J. Econ. Psychol. 28 (1) (2007) 93-112.

25. R.E. Blyth, et al., Voluntary management in an inshore fishery has conservation benefits, Environ. Conserv. 29 (4) (2002) 493-508.

26. K. Brooks, et al., Selecting and assessing social objectives for Australian fisheries management, Mar. Policy 53 (2015) 111-122.

27. J. Burger, Consumption advisories and compliance: the fishing public and the deamplification of risk, J. Environ. Plan. Manag. 43 (4) (2000) 471-488.

28. M. Cabanellas-Reboredo, et al., Estimating harvest and its uncertainty in heterogeneous recreational fisheries, Fish. Res. 188 (2017) 100-111.

29. C.B. Cadsby, E. Maynes, V.U. Trivedi, Tax compliance and obedience to authority at home and in the lab: a new experimental approach, Exp. Econ. 9 (4) (2006) 343-359.

30. C. Chavez, H. Salgado, Individual transferable quota markets under illegal fishing, Environ. Resour. Econ. 31 (3) (2005) 303-324.

31. A. Cinti, et al., The unintended consequences of formal fisheries policies: social disparities and resource overuse in a major fishing community in the Gulf of California, Mexico, Mar. Policy 34 (2) (2010) 328-339.

32. A.M. Cisneros-Montemayor, U.R. Sumaila, A global estimate of benefits from ecosystem-based marine recreation: potential impacts and implications for management, J. Bioecon. 12 (3) (2010) 245-268.

33. F.C. Coleman, et al., The impact of United States recreational fisheries on marine fish populations, Science 305 (5692) (2004) 1958-1960.

34. S. Conly, Against Autonomy, Oxford University Press, Oxford, 2013.

35. S. Cooke, I. Cowx, Contrasting recreational and commercial fishing: searching for common issues to promote unified conservation of fisheries resources and aquatic environ-ments, Biol. Conserv. 128 (1) (2006) 93-108.

36. S. Cooke, I. Cowx, The role of recreational fishing in global fish crises, BioScience 54 (9) (2004) 857-859. 
37. S. Cooke, H. Schramm, Catch-and-release science and its application to conservation and management of recreational fisheries, Fish. Manag. Ecol. 14 (2) (2007) 73-79.

38. S.J. Cooke, et al., The nexus of fun and nutrition: recreational fishing is also about food, Fish. Fish. (2017) 1-24.

39. S.J. Cooke, et al., Voluntary institutions and behaviours as alternatives to formal regulations in recreational fisheries management, Fish. Fish. 14 (4) (2013) 439-457.

40. C. Copeland, et al., Motivations of recreational fishers involved in fish habitat management, Fish. Manag. Ecol. 24 (1) (2017) 82-92.

41. D.L. Costa, M.E. Kahn, Energy conservation "nudges" and environmentalist ideology: evidence from a randomized residential electricity field experiment, J. Eur. Econ. Assoc. 11 (3) (2013) 680-702.

42. I.G. Cowx, Recreational fisheries, in: J. Reynolds (Ed.), Handbook of Fish Biology and Fisheries, vol II, Blackwell Science, Oxford, 2002, pp. 367-390.

43. C. Cvitanovic et al., Building trust among marine protected area managers and community members through scientific research: Insights from the Ningaloo Marine Park, Australia. Marine Policy, 93, pp. 195-206.

44. S. Datta, et al. A behavioral approach to water conservation: evidence from Costa Rica. Policy Research Working Paper 7283. The World Bank, pp. 1-29, 2015.

45. J.E. Dillard, D.L. Bates, Leisure motivation revisited: why people recreate, Manag. Leis. 16 (4) (2011) 253-268.

46. DPIPWE, Department of primary Industries, Parks, Water and Environment. Recreational Sea Fishing Licences for 1 Nov 2017-31 Oct 2018, 2017. Available at: 〈http://dpipwe.tas.gov.au/sea-fishing-aquaculture/recreational-fishing/ recreational-sea-fishing-licences) (accessed 17 October 2017).

47. FAO, Food and Agriculture Organization of the United Nations. Technical Guidelines for Responsible Fisheries: Recreational Fisheries, No. 13. Rome, 2012.

48. P. Ferraro, M. Price, Using non-pecuniary strategies to influence behavior: evidence from a large scale field experiment, Rev. Econ. Stat. 95 (1) (2011) 64-73.

49. C.S. Fischer, The subcultural theory of urbanism: a twentieth-year assessment, Am. J. Sociol. 101 (3) (1995) 543-577.

50. Fisheries Research and Development Corporation. Recreational Fishing, 2016. Available at: 〈http://frdc.com.au/environment/recreational_fishing/Pages/default.aspx〉.(accesse d on February 2017).

51. M.F. Floyd, et al., Social stratification in recreational fishing participation: re- search and policy implications, Leis. Sci. 28 (4) (2006) 351-368.

52. R. Friis, et al., Comparison of three nudge interventions (priming, default option, and perceived variety) to promote vegetable consumption in a self-service buffet setting, PloS One 12 (5) (2017) e0176028.

53. S. Frijlink, J.M. Lyle, An Evaluation of Motivations, Attitudes and Awareness of Tasmanian Recreational Fishers, Tasmanian Aquaculture and Fisheries Institute, University of Tasmania, Hobart, 2010. 
54. GBRMPA, Great Barrier Reef Marine Park Authority. Compliance and Zoning, 2018. Available at: 〈http://www.gbrmpa.gov.au/media-room/latest-news/ compliance) (accessed 13 April 2018).

55. D.A. Gill, et al., Capacity shortfalls hinder the performance of marine protected areas globally, Nature 543 (7647) (2017) 665-669.

56. N.J. Goldstein, R.B. Cialdini, V. Griskevicius, A room with a viewpoint: using social norms to motivate environmental conservation in hotels, J. Consum. Res. 35 (3) (2008) 472-482.

57. Great Barrier Reef Marine Park Amendment Bill, 2001. Available at: 〈https://www.legislation.gov.au/Details/C2004B00881〉 (accessed September 2017).

58. T.J. Green, Compliance Program Evaluation and Optimisation in Commercial and Recreational Western Australian Fisheries, Department of Fisheries, 2009.

59. R. Greiner, et al., Incentive instruments for the sustainable use of marine resources, Ocean Coast. Manag. 43 (1) (2000) 29-50.

60. D.R. Haggarty, S.J.D. Martell, J.B. Shurin, Lack of recreational fishing compliance may compromise effectiveness of Rockfish Conservation Areas in British Columbia, Can. J. Fish. Aquat. Sci. 73 (10) (2016) 1587-1598.

61. J. Haken, Transnational crime in the developing world. Report for Global financial integrity, 2011.

62. P. Hall, Hook, line and Stinkers queensland illegal recreational fishing shame file. The Courier Mail, 2016.

63. P.G. Hansen, The definition of nudge and libertarian paternalism: does the hand fit the glove? Eur. J. Risk Regul. 7 (1) (2016) 1-41.

64. P.G. Hansen, A. Jespersen, Nudge and the manipulation of choice. A framework for the responsible use of nudge approach to behaviour change in public policy, Eur. J. Risk Regul. 4 (1) (2013) 3-28.

65. A. Hatcher, et al., Normative and social influences affecting compliance with fishery regulations, Land Econ. 76 (3) (2000) 448-461.

66. D.M. Hausman, B. Welch, Debate: to nudge or not to nudge, J. Political Philos. 18 (1) (2010) 123-136.

67. L. Haynes, O. Service, B. Goldacre, and D. Torgerson, Test, Learn, Adapt: Developing public policy with randomised controlled trials, Policy Paper published by the Cabinet Office Behavioural Insights Team, 2012, available at www. cabinetoffice.gov.uk (accessed 14 October 2017).

68. G.W. Henry, J.M. Lyle, The National Recreational and Indigenous Fishing Survey, Tasmanian Aquaculture and Fisheries Institute, University of Tasmania, Hobart, 2003.

69. F.R. Homans, J.E. Wilen, A model of regulated open access resource use, J. Environ. Econ. Manag. 32 (1) (1997) 1-21.

70. K.M. Hunt, R.B. Ditton, Perceived benefits of recreational fishing to hispanicAmerican and Anglo Anglers, Human. Dimens. Wildl. 6 (3) (2001) 153-172.

71. L.M. Hunt, S.G. Sutton, R. Arlinghaus, Illustrating the critical role of human dimensions research for understanding and managing recreational fisheries within a social-ecological system framework, Fish. Manag. Ecol. 20 (2-3) (2013) 111-124. 
72. T. Ihde, et al., The increasing importance of marine recreational fishing in the US: challenges for management, Fish. Res. 108 (2011) 268-276.

73. G.B. Jacob, G.R. Mounir, Measuring leisure satisfaction, J. Leis. Res. 12 (1) (1980).

74. S. Jentoft, B. McCay, D. Wilson, Social theory and fisheries co-management, Mar. Policy 22 (4-5) (1998) 423-436.

75. P. John, et al., Nudge, Nudge, Think, Think: Experimenting with Ways to Change Civic Behaviour, Bloomsbury Academic, London, 2011.

76. I. Kaplan, B. McCay, Cooperative research, co-management and the social dimension of fisheries science and management, Mar. Policy 28 (3) (2004) 257-258.

77. M.A.M. Karper, P.F.M. Lopes, Punishment and compliance: exploring scenarios to improve the legitimacy of small-scale fisheries management rules on the Brazilian coast, Mar. Policy 44 (2014) 457-464.

78. A. Keane, et al., The sleeping policeman: understanding issues of enforcement and compliance in conservation, Anim. Conserv. 11 (2) (2008) 75-82.

79. R. Kearney, Fisheries property rights and recreational/commercial conflict: implications of policy developments in Australia and New Zealand, Mar. Policy 25 (1) (2001) 49-59.

80. R.E. Kearney, Co-management: the resolution of conflict between commercial and recreational shers in Victoria, Australia, Ocean Coast. Manag. 45 (4) (2002) 201-214.

81. D.M. King, J.G. Sutinen, Rational noncompliance and the liquidation of Northeast groundfish resources, Mar. Policy 34 (1) (2010) 7-21.

82. D. Kuehn, V. Luzadis, M. Brincka, An analysis of the factors influencing fishing participation by resident anglers, Human. Dimens. Wildl. 18 (5) (2013) 322-339.

83. K. Kuperan, J.G. Sutinen, Blue water crime: deterrence, legitimacy, and compliance in fisheries, Law Soc. Rev. 32 (2) (1998) 309-332.

84. N. Lacetera, Incentives for prosocial activities, IZA World Labor (2016) 1-10.

85. M. Lehner, O. Mont, E. Heiskanen, Nudging - a promising tool for sustainable consumption behaviour? J. Clean. Prod. 134 (2015) 166-177 (January 2016).

86. W.W.C. Lewin, R. Arlinghaus, T. Mehner, Documented and potential biological impacts of recreational fishing: insights for management and conservation, Rev. Fish. Sci. 14 (4) (2006) 305-367.

87. S.X. Li, et al., Giving to government: voluntary taxation in the lab, J. Public Econ. 95 (9-10) (2011) 1190-1201.

88. M. Lowry, B. Molony, M. Keag. Yellowtail Kingfish, Australian Fish Stocks Reports, 2016. Available at: 〈http://fish.gov.au/2014-Reports/Yellowtail_Kingfish〉. (accessed on July 2017).

89. J. Lloret, et al., Biological and socioeconomic implications of recreational boat fishing for the management of fishery resources in the marine reserve of Cap de Creus, Fish. Res. 91 (2-3) (2008) 252-259.

90. K. Ly, et al., A Practitioner's Guide To Nudging, Research Report Series Behavioural Economics in Action. Retrieved from Rotman School of Management, University of To-ronto, 2013. 
91. J. Lyle, S. Tracey, Tasmanian Recreational Rock Lobster and Abalone Fisheries 20142015 Season, Institute for Marine and Antarctic Studies, University of Tasmania, Hobart, 2016.

92. S. MacColl, Unintended Consequences of Enforcement in a Fisheries Institution: Results from an Artefactual Experiment in Tanzania, The University of San Francisco, 2015.

93. C.J.A. MacKenzie, S.P. Cox, Building legitimacy of the recreational fishing sector in mixed commercial-recreational fisheries, Ocean Coast. Manag. 75 (2013) 11-19.

94. B.C. Madrian, D.F. Shea, The power of suggestion: Inertia in 401(k) Participation and Savings Behavior, Q. J. Econ. 116 (4) (2001) 1149-1187.

95. C. Magee, et al., Chasing the thrill or just passing the time? Trialing a new mixed methods approach to understanding heterogeneity amongst recreational fishers based on motivations, Fish. Res. 199 (2018) 107-118.

96. L.J. McCook, et al., Adaptive management of the Great Barrier Reef: a globally significant demonstration of the benefits of networks of marine reserves, Proc. Natl. Acad. Sci. USA 107 (43) (2010) 18278-18285.

97. B.J. McNeil, et al., On the elicitation of preferences for alternative therapies, New Engl. J. Med. 306 (21) (1982) 1259-1262.

98. D.P. McPhee, D. Leadbitter, G.A. Skilleter, Swallowing the bait: is recreational fishing in Australia ecologically sustainable? Pac. Conserv. Biol. 8 (1) (2002) 40-51.

99. G. Michalek, et al. Nudging as a new soft tool in environmental policy. An analysis based on insights from cognitive and social psychology. Discussion Paper recap15 No. 20, October 2015, Viadrina University Frankfurt/O., Germany, 2015.

100. A. Minter, Compliance and Enforcement for Coastal Fisheries Management in Fiji, IUCN Regional Office for Oceania, Suva, Fiji, p.61, 2008.

101. P. Mongin, M. Cozic, Rethinking Nudges, Social Science Research Network, Rochester, NY, 2014 (SSRN Scholarly Paper ID 2529910).

102. O. Mont, M. Lehner, E. Heiskanen, Nudging. A Tool for Sustainable Behaviour? Swedish Environmental Protection Agency, Stockholm, 2014.

103. A.K. Morison, Input and output controls in fisheries management: a plea for more consistency in terminology, Fish. Manag. Ecol. 11 (6) (2004) 411-413.

104. A. Moseley, G. Stoker, Nudging citizens? Prospects and pitfalls confronting a new heuristic, Resour., Conserv. Recycl. 79 (2013) 4-10.

105. S. Mullainathan, R. Thaler, Behavioral Economics, Cambridge, MA, 2000.

106. NFCC, National Fisheries Compliance Committee of the Australian Fisheries Management Forum. Australian Fisheries National Compliance Strategy 2010-2015, 2015.

107. J. Nielsen, An analytical framework for studying: compliance and legitimacy in fisheries management, Mar. Policy 27 (5) (2003) 424-432.

108. J. Nielsen, C. Mathiesen, Important factors influencing rule compliance in fisheries lessons from Denmark, Mar. Policy 27 (5) (2003) 409-416.

109. A.C. North, The effect of background music on the taste of wine, Br. J. Psychol. 103 (3) (2012) 293-301. 
110. A.C. North, D.J. Hargreaves, J. McKendrick, The influence of in-store music on wine selections, J. Appl. Psychol. 84 (2) (1999) 271-276.

111. L. Nøstbakken, Fisheries law enforcement-A survey of the economic literature, Mar. Policy 32 (3) (2008) 293-300.

112. NSW, New South Wales Department of Fisheries. Fisheries compliance enforcement. Department of Primary Industries, 2016. Available at:

〈http://www.dpi.nsw.gov.au/fishing/compliance/fisheries-compliance-enforcement〉 (accessed 8 April 2017).

113. NSW, New South Wales Department of Fisheries. Stiff fine for evading fishing licence I NSW Department of Primary Industries, 2008. Available at:

〈http://www.dpi.nsw.gov.au/content/archive/news-releases/fishing-andaquaculture/2008/ stiff-fine) (accessed 1 August 2017).

114. R. Oda, Y. Kato, K. Hiraishi, The watching-eye effect on prosocial lying, Evolut. Psychol. 13 (3) (2015) 1-5.

115. OECD, Organisation for Economic Co-operation and Development, Behavioural Insights and Public Policy: Lessons from Around the World, OECD Publishing, Paris, 2017.

116. OECD, Organisation for Economic Co-operation and Development, Tackling Environmental Problems with the Help of Behavioural Insights, OECD Publishing, Paris, 2017.

117. C. Panagopoulos, Affect, social pressure and prosocial motivation: field experimental evidence of the mobilizing effects, Political Behav. 32 (3) (2010) 369-386.

118. D. Pauly, D. Zeller, Catch reconstructions reveal that global marine fisheries catches are higher than reported and declining, Nat. Commun. 7 (2016) 10244.

119. S. Pfattheicher, J. Keller, The watching eyes phenomenon: the role of a sense of being seen and public self-awareness, Eur. J. Social. Psychol. 45 (5) (2015) 560-566.

120. J. Putt, D. Nelson, A National Study of Crime in the Australian Fishing Industry. Research and Public Policy Series 76 Australian Institute of Criminology, Australian Government, Canberra, 2007.

121. J. Putt, J. Putt, D. Nelson, Trends \& Issues Fishing Industry. Research and Public Policy Series, Australian Institute of Criminology, Australian Government, Canberra, 2008.

122. A.A.D.A. Read, et al., Optimizing voluntary compliance in marine protected areas: a comparison of recreational fisher and enforcement officer perspectives using multicriteria analysis, J. Environ. Manag. 92 (10) (2011) 2558-2567.

123. R.R. Reno, R.B. Cialdini, C.A. Kallgren, The transsituational influence of social norms, J. Personal. Social. Psychol. 64 (1) (1993) 104-112.

124. C. Schubert, Evolutionary economics and the case for a constitutional libertarian paternalism - a comment on Martin Binder, "should evolutionary economists embrace libertarian paternalism?”, J. Evolut. Econ. 24 (5) (2014) 1107-1113.

125. C. Schubert, Green nudges: do they work? Are they ethical? Ecol. Econ. 132 (2017) 329-342.

126. S. Sethi, R. Hilborn, Interactions between poaching and management policy affect marine reserves as conservation tools, Biol. Conserv. 141 (2) (2008) 506-516. 
127. D.S. Shiffman, et al., Trophy fishing for species threatened with extinction: a way forward building on a history of conservation, Mar. Policy 50 (2014) 318-322.

128. C.B. Smallwood, L.E. Beckley, Spatial distribution and zoning compliance of recreational fishing in Ningaloo Marine Park, north-western Australia, Fish. Res. 125-126 (2012) 40-50.

129. M.G. Sullivan, Illegal angling harvest of Walleyes protected by length limits in Alberta, North Am. J. Fish. Manag. 22 (2011) 1053-1063.

130. C. Sunstein, Misconceptions about nudges, SSRN Electron. J. (2017).

131. C.R. Sunstein, Nudges That Fail. Working Paper, 141, 1, 2015, pp. 1-20, 2016.

132. C.R. Sunstein, Social norms and social roles, Columbia Law Rev. 96 (4) (1996) 903.

133. C.R. Sunstein, L.A. Reisch, Climate-friendly default rules, SSRN Electron. J. (2016).

134. J.G. Sutinen, K. Kuperan, A socio-economic theory of regulatory compliance, Int. J. Soc. Econ. 26 (1999) 174-193.

135. S. Sutton, Personal and situational determinants of catch-and-release choice of freshwater anglers, Hum. Dimens. Wildl. 8 (2) (2003) 109-126.

136. Tasmanian Fisheries. Fishwatch tip-off leads to margate wharf buat up. Facebook Post, 2017. Available at: 〈https://www.facebook.com/FisheriesTasmania/〉 (accessed 17 October 2017).

137. Tasmanian Government, Department of primary Industries, Parks, Water and Environment Tasmanian Recreational Sea Fishing Guide, Hobart, 2016.

138. R.H. Thaler, S. Benartzi, Save More Tomorrow ${ }^{\mathrm{TM}}$ : using behavioral economics to increase employee saving, J. Political Econ. 112 (S1) (2004) S164-S187.

139. R.H. Thaler, C.R. Sunstein, Nudge: Improving Decisions About Health, Wealth, and Happiness, Yale University Press, New Haven, CT, 2008.

140. A.S. Thomas, M.C. Gavin, T.L. Milfont, Estimating non-compliance among recreational fishers: insights into factors affecting the usefulness of the randomized response and item count techniques, Biol. Conserv. 189 (2015) 24-32.

141. A.S. Thomas, T.L. Milfont, M.C. Gavin, New approach to identifying the drivers of regulation compliance using multivariate behavioural models, PLoS ONE 11 (10) (2016) 1-12.

142. S.R. Tracey, et al., Offshore Recreational Fishing in Tasmania 2011/12, Institute for Marine and Antarctic Studies, University of Tasmania, Hobart, 2013.

143. Victorian State Government. 13FISH intelligence reporting line | Enforcement | Fisheries | Agriculture Victoria, 2016. Available at: 〈http://agriculture.vic.gov.au/fisheries/enforcement/13fish-intelligence-reportingline) (accessed 8 April 2017).

144. WA, Western Australia News. Man fined for poaching 180 marron. WAtoday. Available at /http://www.watoday.com.au/wa-news/man-fined-for-poaching-180marron-20091016-h0wy.html) (accessed on January 2018).

145. J. Waldron, It's All for Your Own Good. The New York Review of Books, 2014.

146. Warroora Station. Warroora Station - FAQ - Beach Camping, Fishing and Accommodation, 2016. Available at: 〈http://www.warroora.com/faq.php〉 (accessed 20 April 2017). 
147. Western Australian Department of Fisheries, Fish resources management act 1994, 2010.

148. D. White, A Structural Model of Leisure Constraints Negotiation in Outdoor Recreation, Leisure Sciences 30 (4) (2008) 342-359.

149. M. Whitehead, et al. Nudging all over the World, ESRC Report, Economic and Social Research Council, Swindon and Edinburgh, 2014.

150. M. Wilberg, Estimation of recreational bag limit noncompliance using contact creel sur-vey data, Fish. Res. 99 (2009) 239-332.

151. B. Worm, et al., Rebuilding global fisheries, Science 325 (2009) 578-585.

152. A. Xepapadeas, Regulation and evolution of compliance in common pool resources, Scand. J. Econ. 107 (3) (2005) 583-599.

153. M.A.L. Young, S. Foale, D.R. Bellwood, Impacts of recreational fishing in Australia: historical declines, self-regulation and evidence of an early warning system, Environ. Conserv. 41 (4) (2014) 350-356. 